\title{
Methodology for environmental safety efficiency within environmental conservation activities in construction industry
}

\author{
Elena Voskresenskaya ${ }^{1,{ }^{*}}$, Lybov Vorona-Slivinskaya ${ }^{2}$ and Sergey Panov $^{2}$ \\ ${ }^{1}$ Peter the Great St.Petersburg Polytechnic University, 195251, St. Petersburg, Polytechnicheskaya \\ str., 29, Russia \\ ${ }^{2}$ Saint Petersburg State University of Architecture and Civil Engineering, 190005, St. Petersburg, 2nd \\ Krasnoarmeyskaya St., 4, Russia
}

\begin{abstract}
The article represents the analysis of environmental conservation activity in construction, aimed at ensuring the environmental effect, which is to prevent pollution of natural resources and, therefore, to improve the quality of building materials and products. There comes a need to correctly evaluate the damage that reduces the efficiency of construction production as a result of environmental pollution. Thus, it seems advisable to consider the methodology for evaluating such damage and to analyze the sufficiency of statistical information. The authors have developed a methodology for ecological and economic assessment of the efficiency of environmental conservation activities in construction. The economic efficiency of environmental conservation costs characterizes only a part of the overall social effectiveness of environmental activities. This, however, does not underestimate the role of such indicators, the analysis of which is necessary to choose the most rational activity, which is impossible without quantitative methods and estimates. Therefore, research should be carried out in this field in order to develop practical recommendations for such evaluations.
\end{abstract}

\section{Introduction}

The general economic pattern of natural resources management ensures quality improvement of the environment, increase of work performance in the construction industry, which calls for joint implementation of measures aimed at environment preservation by enterprises in the general system of the construction complex. At the same time, modern methods for planning the development of the construction industry as a whole do not stop the depletion of natural resources and do not sufficiently enhance their rational use.

The use of natural resources, taking into account the specialization of the construction industry, should comply with their extraction plan, processing and manufacturing of building materials and structures on the basis of the ecologization of this process.

\footnotetext{
*Corresponding author: elenvoskr@mail.ru
} 
The main directions in the study of these problems are determined by a group of leading scientific disciplines related to ongoing research. Social, medical and biological, technical, geographic and other sciences [1-5] are studying environmental issues. From the practical point of view, this problem is studied by specific disciplines: technical, agricultural, silvicultural and construction sciences. The authors of the article also drew attention to certain problems of environmental safety of nature conservation activities in construction industry [6-8].

\section{Materials and Methods}

The development of construction is related with the use of various raw materials resources and their processing, associated with the growth of scientific and technological progress and an increase in the volume of construction, which in turn inevitably leads to a violation of the ecological balance. These negative consequences of the construction industry should be eliminated by developing and implementing a set of environmental measures based on innovative approaches, as well as on advanced technologies. The state of the surrounding environment characterizes the habitat and production activity of a human. Often, the concept of the environment includes elements that make up an artificial environment: residential buildings, engineering structures, industrial facilities. All of those affect the environment, health and living conditions as well as the growth of manufacture, especially it exposes construction and operation of urban development projects.

Environmental policy depends on the level of social and economic development of the country, which varies in different countries, but this policy provides solutions to several complex tasks common to all countries. These tasks are: determination of contamination types, when observing, measurement, data analysis, with their further statistical, analytical, cartographic interpretation.

To the present day, aerial and satellite surveys are the main ways to collect data about built-up and intended for construction areas. Their processing gives the most precise assessment of the ecological state, which contributes to the development of rational resource management in general, including built-up areas.

\section{Results}

Construction areas can be divided into three categories, depending on the density: areas with a high built-up density, with a low density and almost free from buildings. The areas of high construction density include: urban industrial agglomerations, regional centers, city industrial centers; urbanized zones, medium and small cities with specialized functions; zones of developing urbanization (small towns, individual plants); rural settlements; areas of developed transport, the main elements of industrial infrastructure.

Areas of low construction density are: areas of agricultural construction; zones of exploited and protected forests; areas of recreation and tourism, resorts; some inland water bodies. Reserves and national parks; protected landscapes for recreation; landscape and rural parks; natural unused land (swamps and peatlands, wetlands, mountains); part of inland water bodies (rivers, lakes) refer to the areas, that are almost free from buildings.

The environmental management plan in construction should be similar to the development plans of other industries, cooperating of this environmental conservation system in some cases, which will increase its efficiency, reduce production costs and improve the state of the environment. At the same time, the higher the number of enterprises or industries in general, the higher the volume of investment in environmental conservation activities should be. 
Comprehensive ecological and economic evaluation and its results sustain the development of a scientifically based system of environmental conservation activities aimed at preventing pollution and improving the state of the environment. Along with the achieved results in the field of establishing and developing the environmental management in construction, there is still no integrity in the legal and regulatory support of environmental management at all levels of production development.

\section{Discussion}

In accordance with the existing methodology for estimating economic efficiency, the analysis of the environmental measures efficiency should be carried out by comparing the cost-effectiveness of environmental protection to the costs themselves. The results of the measures taken to preserve nature can be divided into the primary effect and the final, mainly socio-economic effect. The first of them is associated with a decrease in the negative impact on the environment and improvement of its condition. The final effect is associated with an increase in the standard of living of the population, an increase in the efficiency of public production. At the same time, there are singled out social and economic results of environmental protection.

Referring the primary results of environmental preserving measures to the necessary costs be characterized by the technical and economic efficiency of their implementation. On its basis, it is possible to compare different versions of homogeneous measures to protect individual components of the environment, dwelled on the level of their technical and economic results, which are expressed by natural indicators of the magnitude of the environmental effect per unit of costs. The characteristic of influence, including construction activity, on the environment and natural resources in Russia is shown in Table $1[10]$.

Table 1. The main indicators of the influence of construction activities on the environment and natural resources for 2012-2015.

\begin{tabular}{|l|r|r|r|r|}
\hline Influence indicators & 2012 & 2013 & 2014 & 2015 \\
\hline $\begin{array}{l}\text { Water abstraction from natural } \\
\text { water bodies for use, billion } \mathrm{m}^{3}\end{array}$ & 64.0 & 61.0 & 63.2 & 60.8 \\
\hline $\begin{array}{l}\text { Discharge of contaminated } \\
\text { sewage, billion } \mathrm{m}^{3}\end{array}$ & 15.7 & 15.2 & 14.8 & 14.4 \\
\hline $\begin{array}{l}\text { Emissions of pollutants into the } \\
\text { atmosphere, million tons }\end{array}$ & 19.6 & 18.4 & 17.5 & 17.3 \\
\hline $\begin{array}{l}\text { Production and consumption } \\
\text { waste generation, million tons }\end{array}$ & 5008 & 5153 & 5168 & 5060 \\
\hline
\end{tabular}

Table 2 presents data on investment statistics aimed at preserving the environment and rational use of natural resources in Russia.

Table 2. Investments in fixed assets aimed at preserving the environment and rational use of natural resources in Russia for 2012-2015, million rubles.

\begin{tabular}{|l|r|r|r|r|}
\hline Direction of investments & 2012 & 2013 & 2014 & 2015 \\
\hline $\begin{array}{l}\text { Total expenses for nature } \\
\text { preserving: }\end{array}$ & $\mathbf{1 1 6 5 4 3}$ & $\mathbf{1 2 3 8 0 7}$ & $\mathbf{1 5 8 6 3 6}$ & $\mathbf{1 5 1 7 8 8}$ \\
\hline water resources & 52420 & 59505 & 76315 & 78962 \\
\hline atmosphere & 34626 & 41196 & 55587 & 40120 \\
\hline land resources & 19888 & 13802 & 14540 & 15703 \\
\hline
\end{tabular}


It is important to determine the economic efficiency of environmental conservation activities based on the ratio of the value of its final results and the costs incurred. This raises a number of problems connected with the quantitative determination of such a valuation. When calculating the magnitude of the economic effect, the difficulties are mainly of a technical kind and consist in the need to separate the results of purely environmental conservation activities leading to an improvement in the state of the environment and, accordingly, to the growth of the efficiency in the branches of the national economy associated with their exploitation from the set of factors affecting the increase in the efficiency of social production. Opportunities for monetary estimates of social results of environmental conservation activity are limited not only from the point of view of technical problems of calculating these magnitudes, but also from the positions of methodology.

The total damage from pollution of the environment includes the amounts of damage caused to certain polluted natural components. There is a need to estimate these damages for each component separately, because each has its own specifics and impact on the ecological state of the area.

Dwelling on this, it is possible to formulate a methodology for the environmental and economic assessment of the efficiency of environmental conservation activities in construction, which consists in determining the prevented damage of various types: economic (ecn), environmental (ecl), social (soc), technological (tech), material (mat), which negatively affect the profitability of construction enterprises, increasing the expenses on preventing the damage to the environment, that causes the need to plan additional capital investments to mitigate the arising damages and reduce the production costs. Therefore, the efficiency of environmental conservation activity at a single enterprise can be determined by the following dependency (1):

$$
\mathrm{E}=(\mathrm{ecn}+\mathrm{ecl}+\mathrm{soc}+\mathrm{tech}+\mathrm{mat}) / \sum \text { Total }
$$

Total- total expenses for environmental conservation activity.

In addition, additional investment investments may be planned for the development and implementation of environmental preserving measures, regardless of the quality of natural resources used for building materials and structures. The statistics on the ecological innovations in Russia is presented in Table 3.

Table 3. Ecological innovations for 2012-2015.

\begin{tabular}{|c|c|c|c|c|}
\hline Indicators & 2012 & 2013 & 2014 & 2015 \\
\hline $\begin{array}{c}\text { Percentage of organizations, which implement } \\
\text { ecological innovations, of the total number of } \\
\text { organizations, \% }\end{array}$ & 22.4 & 12.9 & 13.6 & 14.0 \\
\hline $\begin{array}{c}\text { Special costs connected with ecological innovation, } \\
\text { billion rubles }\end{array}$ & 27.8 & 15.1 & 20.9 & 22.0 \\
\hline $\begin{array}{c}\text { Percentage of organizations, which use the } \\
\text { monitoring system over environmental pollution, } \\
\text { of the total number of organizations, \% }\end{array}$ & 12.1 & 10.8 & 11.1 & 10.6 \\
\hline
\end{tabular}

The generalizing index of the efficiency for construction production commensurates the achieved result of this production with actual costs. The efficiency of the construction depends on the amount and quality of the used building materials and structures, as well as the reduction of costs allocated to environmental conservation activity. The final result of additional investments in environmental conservation activities is ecologization of construction and, as a consequence, improvement of the quality of the environment and preservation of public health.

In this regard, the evaluation of the efficiency of environmental costs amid construction and operation is necessary for the following: planning the volume of environmental 
measures and the timing of their implementation; establishing the value of investments distributed to the environmental conservation activities; estimating the value of environmental preserving measures, as well as the rationalization of the use of these investments.

\section{Conclusions}

In the current practice of development and implementation of environmental conservation activities, as well as monitoring over the state of the environment, the real effect is achieved with the timely detection of violations of environmental legislation and imposing of appropriate sanctions against enterprises that fail to comply with environmental preserving measures in full and on time. Development of standards is the main objective in creating a real interest of enterprises in broad environmental conservation activities, establishing a social mechanism for optimal use of the environment. This implies the creation of certain conditions, when it becomes economically unviable for the enterprise to pollute the environment due to justified, effective and tangible penalties. Therefore, the development of standards for such sanctions is a very important objective, but there are many difficulties on the way to its implementation.

It is necessary to divide the damage to the environment into objective, or planned, and to subjective, or unplanned. The first type of damage does not depend on the enterprise itself and it is related to the limited production, material, financial and labor resources that can be allocated by society to environmental conservation activities.

The choice of a place for new enterprises does not always fully meet the needs of environmental protection, as a result of which a certain amount of damage is predetermined. On the other hand, given the limited resources, it is impossible to provide all enterprises with such a volume of treatment facilities that would exclude pollutants from entering the environment. The achievement of this objective is carried out gradually, with a certain order of priority. Thus, some enterprises damage the environment due to the fact that they do not have the waste treatment facilities in the proper amount due to the lack of funds and equipment, i. e., they are placed in conditions that are beyond their control, under which the damage caused by such enterprises to nature is inevitable. To apply in this case any sanctions to the enterprise itself is not justified. In this case, it is not justified to impose sanctions against such enterprises.

However, if the company does not fulfill its approved environmental management plans, it will cause the planned damage to the environment, which should not have taken place. The company must bear responsibility for causing such damage, therefore, it is necessary to evaluate the amount of pollution due to non-fulfillment of the plan and the consequential additional damage.

Thus, the complex process character of environmental conservation activities in construction introduces certain difficulties in assessing the ecological and economic state of the natural environment in this field. However, the solution of these problems raises the need to develop a systematic approach to assessing the efficiency of environmental preserving measures aimed at both the formation of rational environmental management and the protection of the environment as a whole.

\section{References}

1. A.O. Voronin, Predostavlenie zemel' naselennykh punktov dlya stroitel'stva khozyaystvennykh (2009) 
2. I.I. Gordienko, Pravovoe regulirovanie predostavleniya zemel'nykh uchastkov dlya stroitel'stva (2010)

3. V.V. Grechko, Pravovoe regulirovanie predostavleniya zemel'nykh uchastkov dlya zhilishchnogo stroitel'stva iz zemel', nakhodyashchikhsya $v$ gosudarstvennoy $i$ munitsipal'noy sobstvennosti (2013)

4. S.V. Andreev, Zemel'nyy pravoporyadok v oblasti gradostroitel'stva (2007)

5. I.V. Tkacheva, Pravovoe regulirovanie predostavleniya dlya stroitel'stva zemel'nykh uchastkov v gorode Moskve (2008)

6. E. Voskresenskaya, V. Snetkov, A. Tebryaev, Z. Askarov, MATEC Web of Conferences 106, 08055 (2017)

7. E. Voskresenskaya, L. Vorona-Slivinskaya, A. Loiko, Web of Scholar 6(24)-7, 32-37 (2018) doi: 10.31435/rsglobal_wos/12062018/5800

8. E. Voskresenskaya, L. Vorona-Slivinskaya, E3S Web of Conferences 33, 03052 (2018) https://doi.org/10.1051/e3sconf/20183303052

9. P. Khe Sun, L. Vorona-Slivinskaya, E. Voskresenskaya, IOP Conference Series: Earth and Environmental Science 90 (2017) https://doi.org/10.1088/1755-1315/90/1/012073

10. Regiony Rossii, Sotsial'no-ekonomicheskie pokazatel (2017) 